Nova Southeastern University

$10-1-1978$

\title{
A 200 Year Record of Carbon-13 and Carbon-14 Variations in a Bermuda Coral
}

\author{
Y.Nozaki \\ Yale University \\ D. M. Rye \\ Yale University \\ K. K. Turekian \\ Yale University \\ Richard E. Dodge \\ Yale University, dodge@nova.edu \\ Find out more information about Nova Southeastern University and the Halmos College of Natural Sciences \\ and Oceanography.
}

Follow this and additional works at: https://nsuworks.nova.edu/occ_facarticles

Part of the Marine Biology Commons, Meteorology Commons, and the Oceanography Commons

\section{Recommended Citation}

Nozaki, Y., D. M. Rye, K. K. Turekian, and R. E. Dodge. 1978. "A 200 year record of carbon-13 and carbon-14 variations in a Bermuda coral." Geophysical Research Letters no. 5 (10):825-828. doi: 10.1029/GL005i010p00825.

This Article is brought to you for free and open access by the Department of Marine and Environmental Sciences at NSUWorks. It has been accepted for inclusion in Marine \& Environmental Sciences Faculty Articles by an authorized administrator of NSUWorks. For more information, please contact nsuworks@nova.edu. 


\section{VOL. 5, NO. 10,1 \\ A 200 YEAR RECORD OF CARBON-13 AND CARBON-14 VARIATIONS IN A BERMUDA CORAL}

OCTOBER 1978

Y. Nozaki, D.M. Rye, K.K. Turekian and R.E. Dodge

Department of Geology and Geophysics, Yale University, New Haven, Connecticut 06520

Abstract. A 200 year old brain coral, captured in Bermuda in 1976 was slabbed and $x$-rayed. Using the annual growth bands sequential, dated samples were taken over the entire growth period of the coral and analyzed for $\Delta^{14} \mathrm{C}, \delta^{13} \mathrm{C}$ and $\delta^{18} 0$. During the past 80 years atmospheric variations in $\triangle^{14} \mathrm{C}$ and $\delta^{13} \mathrm{C}$ due to human effects, such as release of bomb $\mathrm{C}-14$ and dilution of both $\mathrm{C}-14$ and $\mathrm{C}-13$ by fossil fuel burning, are closely tracked by the coral. Prior to 1900 divergences between the coral and tree $\Delta^{14} \mathrm{C}$ and $\delta^{13} \mathrm{C}$ can be related to world-wide changes in plant production and possibly oceanic upwelling rates.

\section{Introduction}

Direct measurements of the increase of carbon dioxide in the atmosphere, due to man's accelerating use of fossil fuels, have been made over the past $\sim 100$ years with the accuracy of measurements improving over time (Keeling and Bacastow, 1977). The burning of fossil fuels contributes no radiocarbon $\left({ }^{14} \mathrm{C}\right)$, thus causing the ${ }^{14} \mathrm{C} /{ }^{12} \mathrm{C}$ ratio of the atmosphere to decrease. This decrease in the ${ }^{14} \mathrm{C} /{ }^{12} \mathrm{C}$ ratio in the atmosphere has been recorded in tree rings and named the Suess effect after its discoverer (Suess, 1955). Since organic matter is 10 in its ${ }^{13} \mathrm{C} /$ ${ }^{12} \mathrm{C}$ ratio relative to atmospheric $\mathrm{CO}_{2}$ (Craig, 1953) the effect of burning this organic matter is also to diminish the ${ }^{13} \mathrm{C} /{ }^{12} \mathrm{C}$ ratio of the atmosphere. This effect has also been documented using tree rings (Stuiver, 1978).

In addition to the changes in the ${ }^{12} \mathrm{C},{ }^{13} \mathrm{C}$ and ${ }^{14} \mathrm{C}$ content of the atmosphere due to fossil fuel burning, changes due to other effects have also been found. These include: (1) the marked ${ }^{14} \mathrm{C} /{ }^{12} \mathrm{C}$ ratio increase since about 1954 due to nuclear bombs; (2) natural fluctuations in the ${ }^{14} \mathrm{C} /{ }^{12} \mathrm{C}$ ratio over the past 8000 years, the causes for which there is not yet complete agreement - Damon et al (1978) have called this the "deVries effect"; and (3) decrease of the ${ }^{3} \mathrm{C} /{ }^{12} \mathrm{C}$ ratio in the atmosphere commencing before the beginning of the fossil fuel burning (as marked by the Suess effect)which Stuiver (1978) ascribes to increased human burning of trees.

Actually the measured increase in atmospheric $\mathrm{CO}_{2}$ over time is about half of that expected from the known amount of fossil fuel burning (Keeling and Bacastow, 1977). The other half then must be stored in the land (and pcssibly oceanic) biosphere as organic matter and in the ocean as inorganic carbon.

The evidence for the involvement of the ocean is most strikingly seen in the increase in the ${ }^{14} \mathrm{C} /{ }^{12} \mathrm{C}$ ratio in the surface waters of the oceans due to the addition of nuclear bomb produced ${ }^{14} \mathrm{C}$ since about 1954 (see, for example, references in

Copyright 1978 by the American Geophysical Union.
Fig. 2). The surface ocean, however, is less homogeneous in its record of the ${ }^{14} \mathrm{C} /{ }^{12} \mathrm{C}$ ratio than the atmosphere (see, for example, Stuiver, 1978) and, in the absence of long term synoptic analyses of surface waters from around the world, we must turn to the one, long term in situ oceanic detector at our disposal: the calcareous tests of organisms. Most organisms with calcareous tests, deposit bands that can often, but not always, be related to well-known periodic changes in the environment, arising from lunar, daily, seasonal or annual cycles. The calcium carbonate depositing organisms with the longest, we11defined periodic records are the reef-building corals. The continuous growth for hundreds of years makes some corals such as Diploria, the brain coral, ideal recorders of the changing carbon isotopic composition of the local surface ocean. Dodge and Thomson (1974) have used ${ }^{228} \mathrm{Ra}$ and $210 \mathrm{~Pb}$ to determine the annual nature of the bands in this coral. We have systematically analyzed for the carbon isotopes in one such coral from Bermuda. This coral was "born" in 1770 and was captured for this study about 200 years later in July, 1976.

\section{Sampling and analytical methods}

The brain coral (Dibloria labyrinthiformis) was collected, with the assistance of a scuba diver and winch, from a reef 5 meters in depth near North Rock, Bermuda, in July, 1976. Once ashore the specimen was rough slabbed with a masonry chain saw and then resectioned with a geologic rock saw to obtain a parallel sided slab of uniform thickness (about $0.6 \mathrm{~cm}$ ). The $\mathrm{slab}$ was then $\mathrm{x}$-radiographed using Kodak AA Industrial $\mathrm{X}$-ray film to expose annual density band couplets (Dodge and Thomson, 1974). A positive print of the $x$-radiograph was obtained and bands at depth were assigned ages from the known collection date of the coral surface. Referring to this $x$-radiograph, 3-5 year bands were successively chipped off from the outer part, the time interval increasing with depth to 15 years for the deepest sample in order to obtain a sufficient amount (about $25 \mathrm{~g}$ ) for the radiocarbon determination.

Radiocarbon was determined using the liquid scintillation counting technique of benzene described earlier (Nozaki and Turekian, 1977). The $\Delta^{14} \mathrm{C}$ values were calculated using the following equations (Broecker and 01son, 1961):

and

$$
\delta^{14} \mathrm{C}=\left(\frac{\mathrm{A}_{S}}{0.95 \times \mathrm{A}_{\mathrm{ox}}}-1\right) \times 1000 \% \text { 。 }
$$

$$
\Delta^{14} \mathrm{C}=\delta^{14} \mathrm{C}-\left(2 \delta^{13} \mathrm{C}+50\right)\left(1+\frac{\delta^{14} \mathrm{C}}{1000}\right) \% \text { 。 }
$$

where $A$ is the ${ }^{14} \mathrm{C} /{ }^{12} \mathrm{C}$ ratio in $\mathrm{NBS}$ oxalic acid standarg and $\mathrm{A}_{S}$ is the ${ }^{14} \mathrm{C} /{ }^{12} \mathrm{C}$ ratio in the sam- 

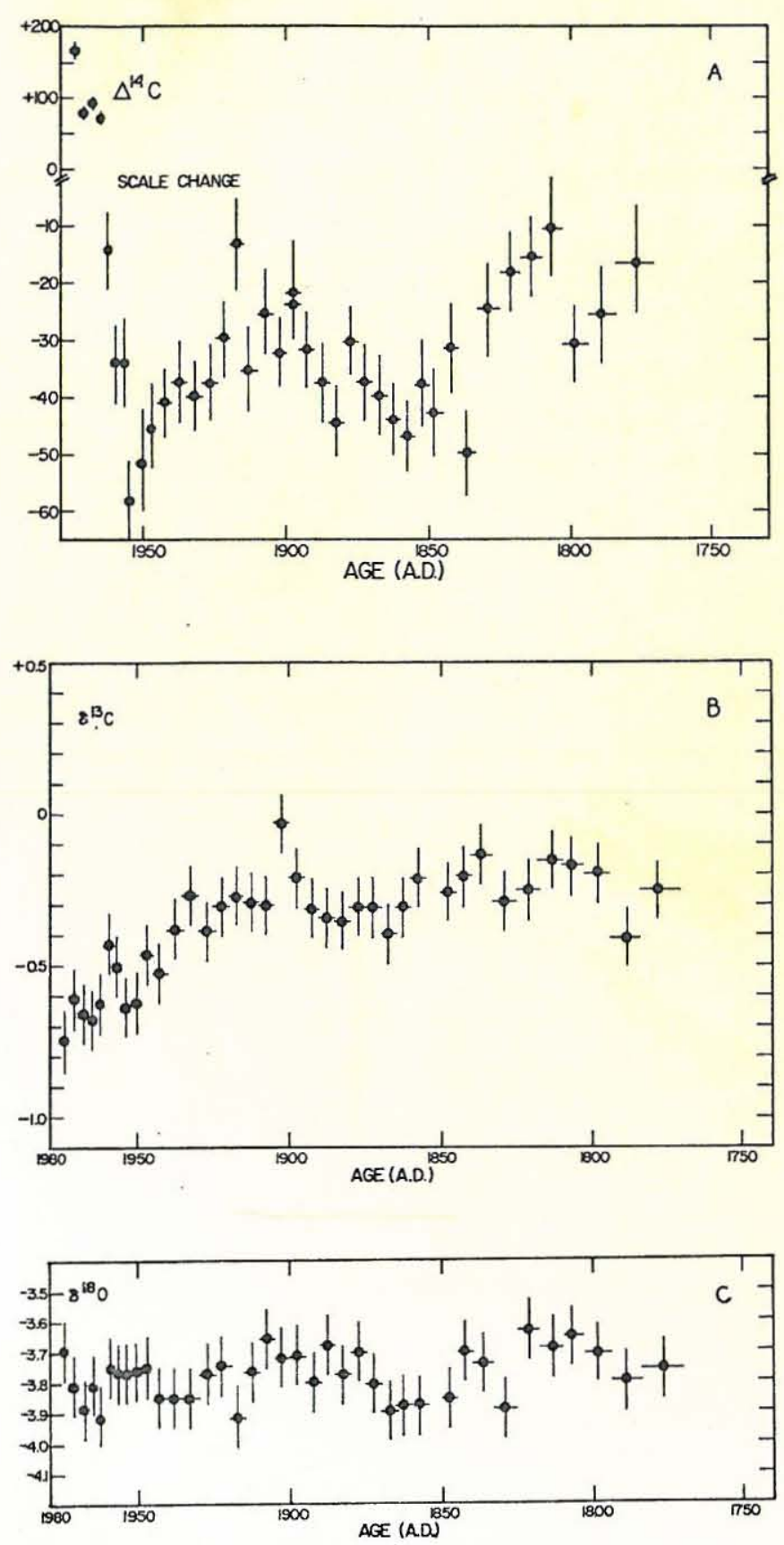

Fig. 1. (A) $\Delta^{14} \mathrm{C}$, (B) $\delta^{13} \mathrm{C}$ and (C) $\delta^{18} 0$ distributions with age in a Bermuda brain coral (Dip1oria). Error bars are $\pm 1 \sigma$.

ple. For samples before 1950 A.D. A was corrected for decay using a half life of 5930 years. No decay correction was made for samples after 1950 A.D. Errors are counting errors at the $1 \sigma$ level. Separate aliquots of each sample were analyzed for $\delta^{13} \mathrm{C}$ and $\delta^{18} 0$. All samples were roasted at $400^{\circ} \mathrm{C}$ in vacuun for 30 minutes prior to dissolving in $100 \%$ phosphoric acid at $25^{\circ} \mathrm{C}$ to release $\mathrm{CO}_{2}$. The analyses of the $\mathrm{CO}_{2}$ were made on a Nuclide 6-60 ratio mass spectrometer. The $\delta^{13} \mathrm{C}$ and $\delta^{18} O$ are reported relative to $\mathrm{PDB}$. The precision, based on replicate determinations, is $\sim 0.1 \%$ f for both carbon and oxygen.

Figure 1 shows the results for our "bicentennial" coral.

\section{Discussion}

Our fundamental premise is that a coral records the ambient carbon isotopic composition of surrounding ocean as it grows. Secondary effects due to the local oxidation of organic matter have been reported (Weber and Woodhead, 1972). This will cause the carbon isotopic composition of the depositing calcium carbonate to be lighter than the ambient water carbonate. The oxygen isotopic composition of hermatypic corals show a strong correlation with temperature as expected but are clearly offset from the expected equilibrium values, also the result of metabolic effects. We note from Figure 1 that the variation of $\delta^{18} 0$ is very small and, thus we assume that the organic metabolic isotopic effect is also small and constant for carbon.

As a matter of convenience we can imagine two water types influencing the coral. The first is a surface water in complete exchange equilibrium with the atmosphere so far as carbon isotopic exchange is concerned. The second is water supplied from depth where it had been isolated from the atmosphere for a long period of time resulting in a carbon isotope complexion determined by long term deep-sea processes rather than by equilibration with the atmosphere. The coral can be expected to record the variation in relative contributions of carbon from the two reservoirs averaged over the sampling period.

\section{The Nuclear Bomb ${ }^{14} \mathrm{C}$ Increase}

The $\Delta^{14} \mathrm{C}$ values from 1950 to 1976 in the coral are shown in Figure 2 together with measurements made over time on ocean water from the Sargasso Sea $\left(15^{\circ} \mathrm{N}\right.$ to $\left.40^{\circ} \mathrm{N}\right)$ by a number of investigators. The pattern in both the corals and the surface sea water samples indicates an increase in ${ }^{14} \mathrm{C}$ since 1955. Between 1967 and 1973, however, the coral data appear to be lower than the general Sargasso Sea values. The most simple explanation of this fact is that during this six year period supply of the deep component locally influenced the water in which the coral was growing relative to ambient "equilibrated" Sargasso Sea water. A similar effect was reported by Moore and Krishna-

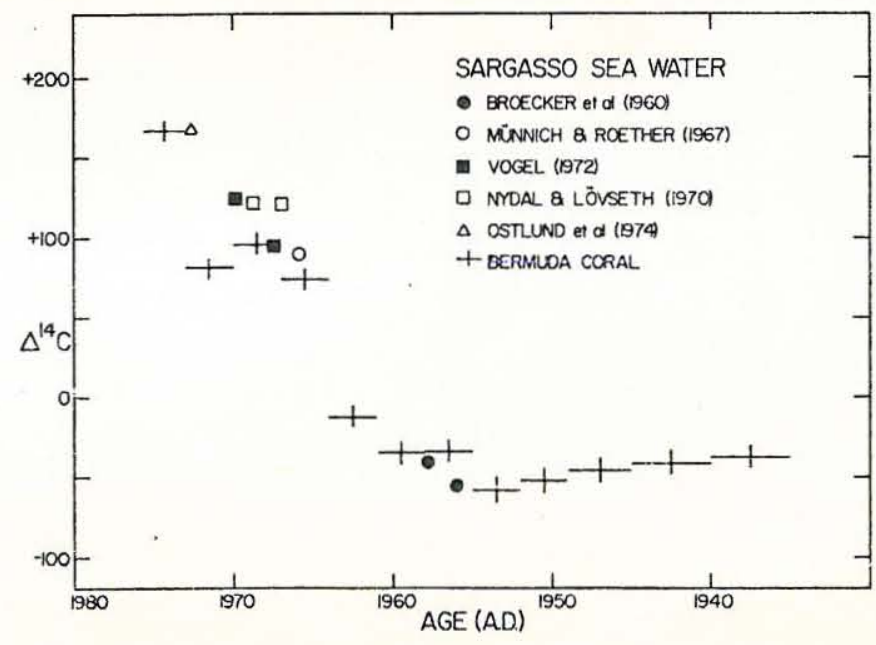

Fig. 2. Comparison of $\triangle^{14} \mathrm{C}$ in post-bomb coral bands with published surface Sargasso sea values. 


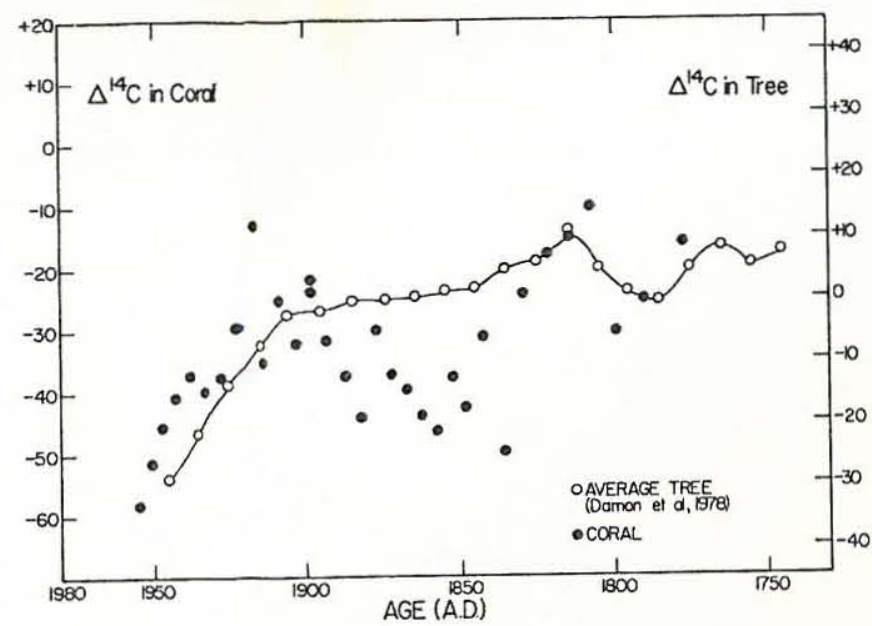

Fig. 3. Compartson of $\Delta^{14} \mathrm{C}$ in tree rings (summarized by Damon et al, 1978) and in Diploria prior to 1950 .

swami (1974) for a coral they analyzed for ${ }^{14} \mathrm{C}$ from the Gulf of Kutch in the Indian Ocean.

\section{The Suess Effect}

There is a virtually monotonic decrease in ${ }^{14} \mathrm{C}$ in the coral record from 1900 to 1955 which appears to demonstrate the Suess effect. When the coral trend from 1900 and 1955 is compared with the tree ring trend from data compiled by Damon et al (1978), it is evident that the coral data are lighter than the contemporaneous tree ring values throughout this time by about 25\%。(Fig. 3). The sustained $25 \%$ offset between Sargasso Sea surface water and trees indicates that the $\mathrm{CO}_{2}$ gas exchange between the surface ocean in this location and the atmosphere must be very rapid.

In Figure 4, the $\delta^{13} \mathrm{C}$ values for the Bermuda coral over the past 80 years is compared to the avallable data on tree rings. (As there is no bomb effect for ${ }^{13} \mathrm{C}$ the full record after 1900

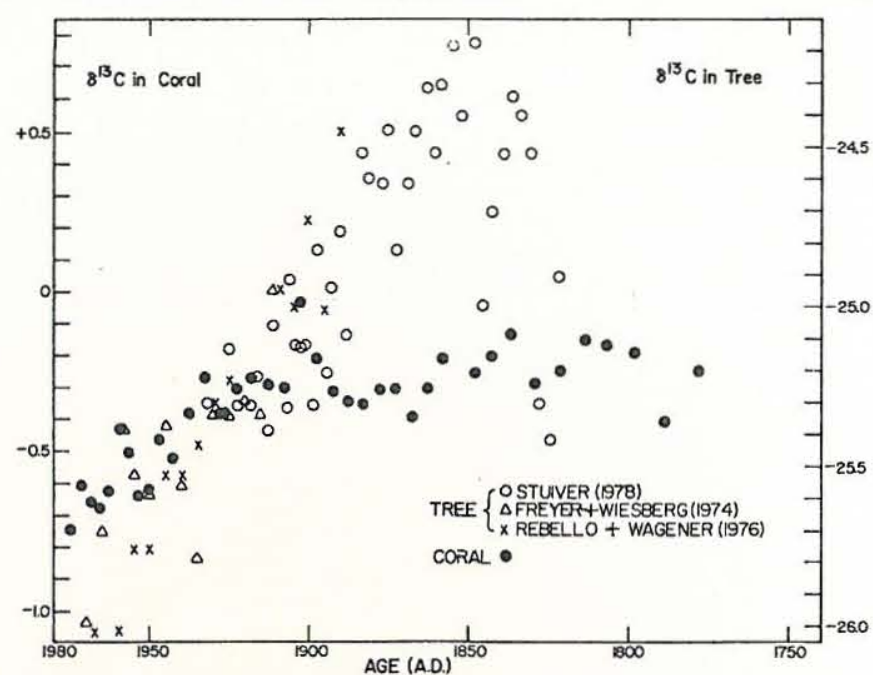

Fig. 4. Comparison of $\delta^{13} \mathrm{C}$ in tree rings and in Diploria.

can be used). The decrease in $\delta^{13} \mathrm{C}$ in both the tree and coral over this time period can also be ascribed to the dilution of atmospheric carbon with fossil fuel carbon.

Table 1 shows that the changes in both $\Delta^{14} \mathrm{C}$.. and $\delta^{13} \mathrm{C}$ between 1900 and 1950 observed in our coral are about $80 \%$ of those observed in trees. The global box diffusion model of Oeschger et al (1975) predicts that the world-wide surface ocean response should be $40 \%$ of that in the atmosphere. This difference between the model value and the coral value can be ascribed to the relatively rapid exchange of $\mathrm{CO}_{2}$ across the sea surface and the relatively small exchange rate with deep water in this region of the Sargasso Sea relative to the average for the world oceans.

Variations in $\Delta^{14} \mathrm{C}$ and $\delta^{13} \mathrm{C}$ in the Coral between 1770 A.D. and 1900 A.D.

We have seen that to a good first approximation the $\Delta^{14} \mathrm{C}$ and $0^{13} \mathrm{C}$ record of the first 76

TABLE 1: $\triangle^{14} \mathrm{C}$ and $\delta^{1{ }^{3} \mathrm{C}}$ changes between 1900 and $1950 \mathrm{~A}$.D. in the Bermuda coral and trees compared to the Oeschger et al (1975) box diffusion model

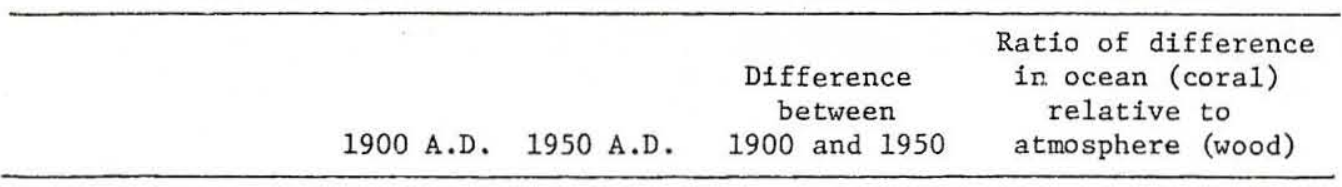

A. Observed values

$\begin{array}{cccccc}\Delta{ }^{14} \mathrm{C} & \text { Coral } & -28 & -50 & -22 & 0.79 \\ & \text { Wood } & -2 & -30 & -28 & \\ \delta^{13} \mathrm{C} & \text { Coral } & -0.15 & -0.55 & -0.40 & 0.80 \\ & \text { Wood } & -25.2 & -25.7 & -0.50 & \end{array}$

B. Box diffusion model values from Oeschger et al (1975)

$\begin{array}{cccc}\Delta^{14} \mathrm{C} \quad \begin{array}{c}\text { Surface } \\ \text { ocean }\end{array} & -52.3 & -58.0 & -5.7 \\ & \text { Atmosphere }-5.0 & -19.5 & -14.5\end{array}$


years of the present century, with its large changes due to the actions of man, is recorded by the Bermuda coral virtually to the same extent as by the trees. We now explore the relationship between the two detectors prior to 1900. Between $1830 \mathrm{~A} . \mathrm{D}$. and $1900 \mathrm{~A} . \mathrm{D}$., the $\Delta^{14} \mathrm{C}$ values in wood are nearly constant, whereas those in coral are depressed by $\sim 20 \%$ o relative to the wood trend (Fig. 3). In the same period, the atmospheric ${ }^{13} \mathrm{C}$ values appear to have a strong peak (reaching up to $1 \%$ ) around 1855 A.D., whereas those in the coral are approximately constant (Fig. 4). If oceanographic conditions in the western Sargasso Sea remained constant over the last two hundred years, the atmospheric variation in both ${ }^{13} \mathrm{C}$ and ${ }^{14} \mathrm{C}$ should be tracked by the surface ocean as sensed by the growing coral as was seen between 1900 and 1976. This of course is not borne out by the facts.

We believe that the most likely explanation for the observed depression of $\Delta^{1{ }^{4}} \mathrm{C}$ and $\delta^{1{ }^{3} \mathrm{C}}$ in the coral relative to the expected values inferred from the tree data during the period 1830 and 1900 is enhanced local upwelling. Broecker et al (1960) indicate that the pre-bomb sub-surface water in the Sargasso Sea had an average $\Delta^{14} \mathrm{C}$ value of $-60 \%$ at depths between 200 and 400 meters and $-105 \%$ 。 below 400 meters in 1957 to 1959 A.D. Although the sub-surface water values in the 1950's may have been affected by the Suess effect to some extent, it seems possible to depress the surface ${ }^{14} \mathrm{C}$ values by $20 \%$ omore than expected from an equilibrated ambient surface water by the out-crop of the sub-surface water above the thermocline or by increased vertical diffusion.

Wherever it comes from, this deeper component will carry with it a lighter $\delta^{13} \mathrm{C}$ carbon than the ambient equilibrated surface water has. Since the present day sub-surface water of the Sargasso Sea is lighter by $\sim 0.5 \%$ 。 than the surface water (Kroopnick et al, 1972). In order to maintain a constant $\delta^{13} \mathrm{C}$ value for the water from which the coral deposits its calcareous test, there must be a compensatory preferential removal of ${ }^{12} \mathrm{C}$ relative to ${ }^{13} \mathrm{C}$ on a shorter time scale than the atmospheric equilibration rate of about 12 years (Broecker and Peng, 1975). Thus we believe that photosynthesis by marine plants with subsequent removal of low $\delta^{13} \mathrm{C}$ organic carbon from the surface layer maintains the $\delta^{13} \mathrm{C}$ in the surface ocean independent of atmospheric equilibration at times of upwelling. The maintenance of this level may derive directly from the fact that the upwelling water with the lighter $\delta^{13} \mathrm{C}$ component is also rich in nutrient elements and thereby enhances the productivity in the surface ocean with consequent net removal of isotopically light organic matter.

Acknowledgments. This research was supported by NSF Grant OCE 76-02039. The field work was based at the Bermuda Biological Station and we wish to thank the Director and staff for their assistance.

\section{References}

Broecker, W.S. and T.H. Peng, Gas exchange rates between air and sea, Tellus, 24, 21-35; 1975.

Broecker, W.S. and E. O1son, Lamont radiocarbon measurements. VIII Radiucarbon, 3, 176-204, 1961.
Broecker, W.S., R. Gerard, M. Ewing and B.C. Heezen, Natural radiocarbon in the Atlantic Ocean, J. Geophys. Res., 65, 2903-2931, 1960.

Craig, H., The geochemistry of the stable carbon isotopes, Geochim. Cosmochim. Acta, 3, 53-92, 1953.

Damon, P.E., J.C. rman and A. Long, Temporal fluctuations of wospheric ${ }^{14} \mathrm{C}$ : Causal factors and implications, inn. Rev. Earth Planet. Sci., 6, 457-494, 1978 .

jodge, R.E. and J. Thomson, The natural radiochemical and growth records in contemporary hermatypic corals from the Atlantic and Caribbean, Earth Planet. Sci. Lett, 23, 313-322, 1974.

Freyer, H.D. and L. Wiesberg, Dendrochronology and ${ }^{13} \mathrm{C}$ content in atmospheric $\mathrm{CO}_{2}$, Nature, 252, 757, 1974.

Keeling, C.D. and R.B. Bacastow, Impact of industrial gases on climate, 72-95, in Energy and Climate, National. Academy of Science, Washington, D.C., 1977.

Kroopnick, P., R.F. Weiss and H. Craig, Total $\mathrm{CO}_{2},{ }^{13} \mathrm{C}$, and dissolved oxygen -180 at GEOSECS II in the North Atlantic, Earth Planet. Sci. Lett.,16, 103-110, 1972.

Moore, W.S and S. Krishnaswami, Correlation of $\mathrm{X}$-radiography revealed banding in corals with radiometric growth rates, Proc. 2nd Int. Symp. on Coral Reefs, Vol. 2, 269-276, 1974.

Münnich, K.O. and W. Roether, Transfer of bomb ${ }^{14} \mathrm{C}$ and tritium from the atmosphere to the ocean. Internal mixing of the ocean on the basis of tritium and ${ }^{14} \mathrm{C}$ profiles, in Radioactive Dating and Methods of Low-level Counting, IAEA, Vienna, 119-128, 1967.

Nozaki, Y. and K.K. Turekian, Yale University Geology and Geophysics Radiocarbon dates I. Radiocarbon, 19, 138-141, 1977.

Nydal, R. and K. Lövseth, Prospective decrease in atmospheric radiocarbon, J. Geophys. Res., 75, 2271-2278, 1970.

Oeschger, H., U. Siegenthaler, U. Schotterer, and A. Gugelmann, A box diffusion model to study the carbon dioxide exchange in nature, Tellus, $27,168,1975$.

Ostlund, H.G.,H.G. Dorsey and C.G. Rooth, GEOSECS North Atlantic radiocarbon and tritium results, Earth Planet. Sci. Lett., 23, 69-86, 1974 .

Rebello, A. and K. Wagener, Evaluation of ${ }^{12} \mathrm{C}$ and ${ }^{13} \mathrm{C}$ data on atmospheric $\mathrm{CO}_{2}$ on the basis of a diffusion model for oceanic mixing, in Environmental Biogeochemistry (ed. J.0. Nriagu) Vol. 1, 13-23, Ann Arbor Sci. Publ. Inc., Ann Arbor, Mich., 1976.

Stuiver, M., Atmospheric carbon dioxide and carbon reservoir changes, Science, 199, 253-258, 1978.

Suess, H., Radiocarbon concentration in modern wood, Science, 122, 414-417, 1955.

Vogel, J.C., Radiocarbon in the surface waters of the Atlantic Ocean, Proc. 8th Int. Conf. on Radiocarbon Dating, Vol. 1, 267-279, 1972.

Weber, J.N. and P.M. Woodhead, Temperature dependence of oxygen-18 concentration in reef coral carbonates, J. Geophys. Res., 77, 463$473,1972$.
(Received July 24, 1978; accepted August 21, 1978.) 